\title{
Monitoring of infections by Protozoa of the genera Nematopsis, Perkinsus and Porospora in the smooth venus clam Callista chione from the North-Western Adriatic Sea (Italy)
}

\author{
G. Canestri-Trotti ${ }^{1, *}$, E. M. Baccarani ${ }^{1}$, F. Paesanti ${ }^{2}$, E. Turolla ${ }^{2}$ \\ ${ }^{1}$ Dipartimento di Biologia Animale e dell'Uomo, Università degli Studi di Torino, Via Accademia Albertina, 17, 10123 Torino, Italy \\ ${ }^{2}$ Goro Acquicoltura s.r.l., P. le Leo Scarpa, 45, 44020 Goro (Ferrara), Italy
}

\begin{abstract}
Marketable smooth venus clams Callista chione from natural banks of Chioggia (Venice) and Goro (Ferrara), North-Western Adriatic Sea (Italy), were examined for protozoan parasites from November 1996 to November 1998. Out of the 375 bivalves examined, 149 (39.7\%) were infected by Nematopsis sp. and 325 (86.7\%) by Porospora sp. Oocysts of Nematopsis sp. were present with a prevalence that varied from $100 \%$ in November 1996 to 5\% in June 1998; cystic and naked sporozoites of Porospora sp. were very common, with a prevalence of $100 \%$. Out of the 229 bivalves examined between January and November 1998, 63 (27.5\%) were also infected by Perkinsus sp.; the prevalence of Perkinsus sp. varied from $9.1 \%$ in January to $50 \%$ in February. To our knowledge this is the first report of Porospora sp. and Perkinsus sp. in C. chione.
\end{abstract}

KEY WORDS: Callista chione - Nematopsis sp. P Porospora sp. · Perkinsus sp. · Parasitology · Epidemiology

\section{Resale or republication not permitted} without written consent of the publisher

The smooth venus clam Callista chione (Bivalvia: Veneridae) (syn.: Pitaria chione, Pitar chione, Meretrix chione, Cyterea chione, Macrocallista chione; Fasolaro [Italian], Verni [French], braune Venus Muschel [German], Almejon brillante [Spanish]) lives on sandy or muddy bottoms of the Mediterranean Sea. It is actively fished along the Emilia-Romagna, Venetian and Friuli coasts of the Northern Adriatic Sea (Italy). Despite its economic importance, there is a deep lack of information about its health status. To provide a baseline health status of the marketable $C$. chione from the Northern Adriatic Sea, we performed a survey of its protozoan parasites.

Materials and methods. From November 1996 to November 1998, 17 Callista chione samples of marketable

*E-mail: canestri@dba.unito.it size (50 to $65 \mathrm{~mm}$ ) were collected for a total of 375 specimens (aged 4 to $6 \mathrm{yr}$ after Marano et al. 1998): 357 specimens from Chioggia (Venice) and 18 specimens from Goro (Ferrara) (Table 1). Sections $\left(1 \mathrm{~cm}^{2}\right)$ of gill, mantle and foot tissues were squashed between glass slides and examined for the presence of Nematopsis (Apicomplexa: Porosporidae) oocysts and Porospora (Apicomplexa: Porosporidae) sporozoites (Bower et al. 1994).

On the grounds that Perkinsus (Apicomplexa: Perkinsidae) infections were suspected, between January and November 1998 gill fragments of 229 bivalves were also placed in fluid thioglycollate medium (FTM) and examined microscopically after $10 \mathrm{~d}$ for the presence of hypnospores (Ray 1952).

The number of parasites was evaluated per microscope field at $400 \times$.

Results. In the gills and mantle, Nematopsis sp.infected bivalves were identified by the presence of oval oocysts (Fig. 1) measuring 8.1-16.6 × 5.3-11.1 $\mu \mathrm{m}$ and having a thick transparent wall, about $0.5 \mu \mathrm{m}$ in width. One of the 2 poles of the oocyst appeared slightly pointed because of the presence of an operculum covering the micropyle. A single short and stocky vermiform sporozoite was often easily distinguishable inside the oocyst. The mean prevalence of Nematopsis sp. infection was $39.7 \%$, ranging from $100 \%$ observed in November 1996 to $5 \%$ in June 1998 (Table 1). In infected specimens, the oocysts ( $\mathrm{n}=1$ to 31 per microscope field) appeared irregularly distributed in gill and mantle connective tissue; in the same subjects we observed isolated oocysts or clusters of 10 to 25 parasites.

In gill, mantle and foot connective tissues, Porospora sp.-infected bivalves were identified by the presence of either sporozoites enclosed within a thin ellipsoidal cystic membrane, measuring 40.6-131.5 × 14.3-88.6 $\mu \mathrm{m}$ 
Table 1. Callista chione. Month, year, locality and number of molluscs examined per sample; prevalence of Nematopsis sp., Porospora sp. and Perkinsus sp.

\begin{tabular}{|c|c|c|c|c|c|c|c|c|c|}
\hline \multirow[t]{2}{*}{ Month } & \multirow[t]{2}{*}{ Year } & \multirow[t]{2}{*}{ Locality } & \multirow{2}{*}{$\begin{array}{c}\text { No. of } \\
\text { molluscs } \\
\text { examined }\end{array}$} & \multicolumn{2}{|c|}{$\begin{array}{c}\text { Nematopsis sp. } \\
\text { infected }\end{array}$} & \multicolumn{2}{|c|}{$\begin{array}{l}\text { Porospora sp. } \\
\text { infected }\end{array}$} & \multicolumn{2}{|c|}{$\begin{array}{l}\text { Perkinsus sp } \\
\text { infected }\end{array}$} \\
\hline & & & & No. & $\%$ & No. & $\%$ & No. & $\%$ \\
\hline Nov & 1996 & Chioggia & 16 & 16 & 100.0 & 16 & 100.0 & - & - \\
\hline Dec & 1996 & Chioggia & 15 & 13 & 86.7 & 14 & 93.3 & - & - \\
\hline Feb & 1997 & Chioggia & 20 & 4 & 20.0 & 19 & 95.0 & - & - \\
\hline Apr & 1997 & Chioggia & 15 & 6 & 40.0 & 9 & 60.0 & - & - \\
\hline May & 1997 & Chioggia & 36 & 14 & 38.9 & 36 & 100.0 & - & - \\
\hline Oct & 1997 & Chioggia & 19 & 18 & 94.7 & 19 & 100.0 & - & - \\
\hline Nov & 1997 & Chioggia & 25 & 19 & 76.0 & 25 & 100.0 & - & - \\
\hline Jan & 1998 & Chioggia & 22 & 8 & 36.4 & 22 & 100.0 & 2 & 9.1 \\
\hline Feb & 1998 & Goro & 18 & 4 & 22.2 & 18 & 100.0 & 9 & 50.0 \\
\hline Mar & 1998 & Chioggia & 15 & 9 & 60.0 & 2 & 13.3 & 3 & 20.0 \\
\hline Apr & 1998 & Chioggia & 22 & 5 & 22.7 & 16 & 72.7 & 6 & 27.3 \\
\hline May & 1998 & Chioggia & 40 & 7 & 17.5 & 40 & 100.0 & 11 & 27.5 \\
\hline Jun & 1998 & Chioggia & 20 & 1 & 5.0 & 20 & 100.0 & 9 & 45.0 \\
\hline Jul & 1998 & Chioggia & 18 & 5 & 27.8 & 18 & 100.0 & 3 & 16.7 \\
\hline Aug & 1998 & Chioggia & 30 & 4 & 13.3 & 30 & 100.0 & 5 & 16.7 \\
\hline Oct & 1998 & Chioggia & 22 & 12 & 54.5 & 15 & 68.2 & 9 & 41.0 \\
\hline Nov & 1998 & Chioggia & 22 & 4 & 19.2 & 6 & 27.3 & 6 & 27.3 \\
\hline Total & & & 375 & 149 & 39.7 & 325 & 86.7 & 63 & 27.5 \\
\hline
\end{tabular}

(Fig. 2), or naked vermiform sporozoites, with an evident dome-shaped end, which moved in the host tissue by means of successive contractions and measured about $31 \times 5.6 \mu \mathrm{m}$ (Fig. 3). The mean prevalence of

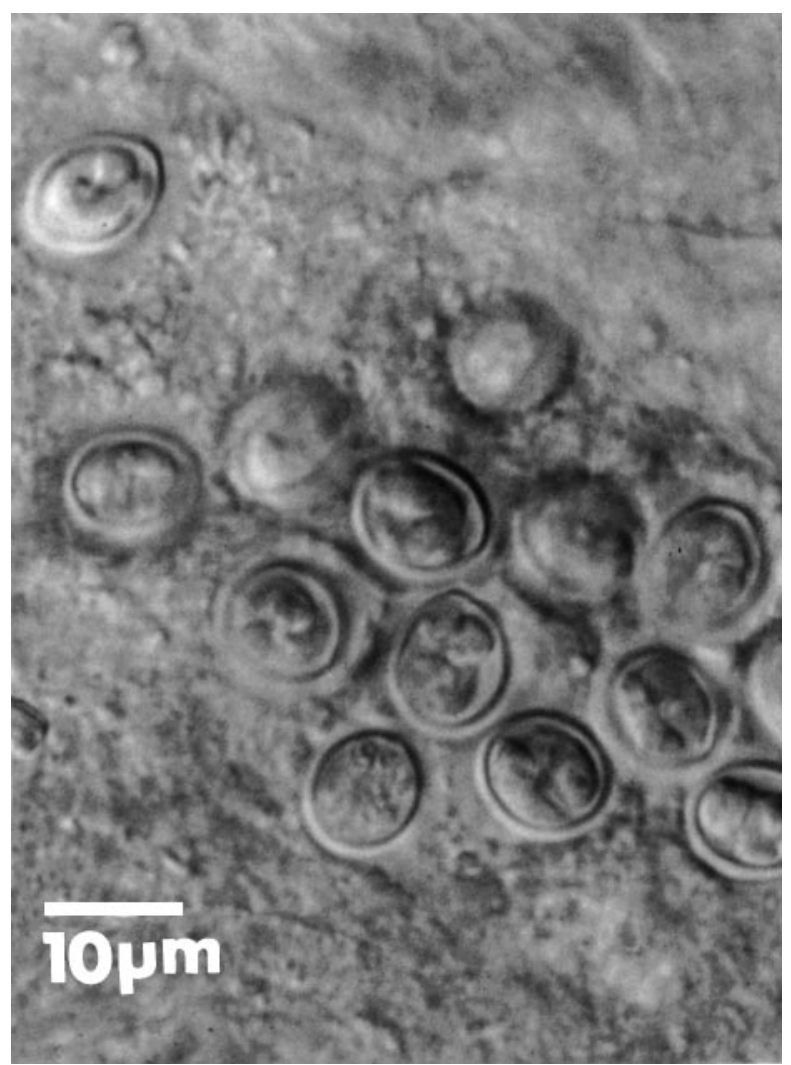

Fig. 1. Nematopsis sp. oocysts in Callista chione
Porospora sp. infection was $86.7 \%$, ranging from $100 \%$ observed in November 1996, May, October and November 1997, and January, February, May, June, July and August 1998 to 13.3\% in March 1998 (Table 1). In

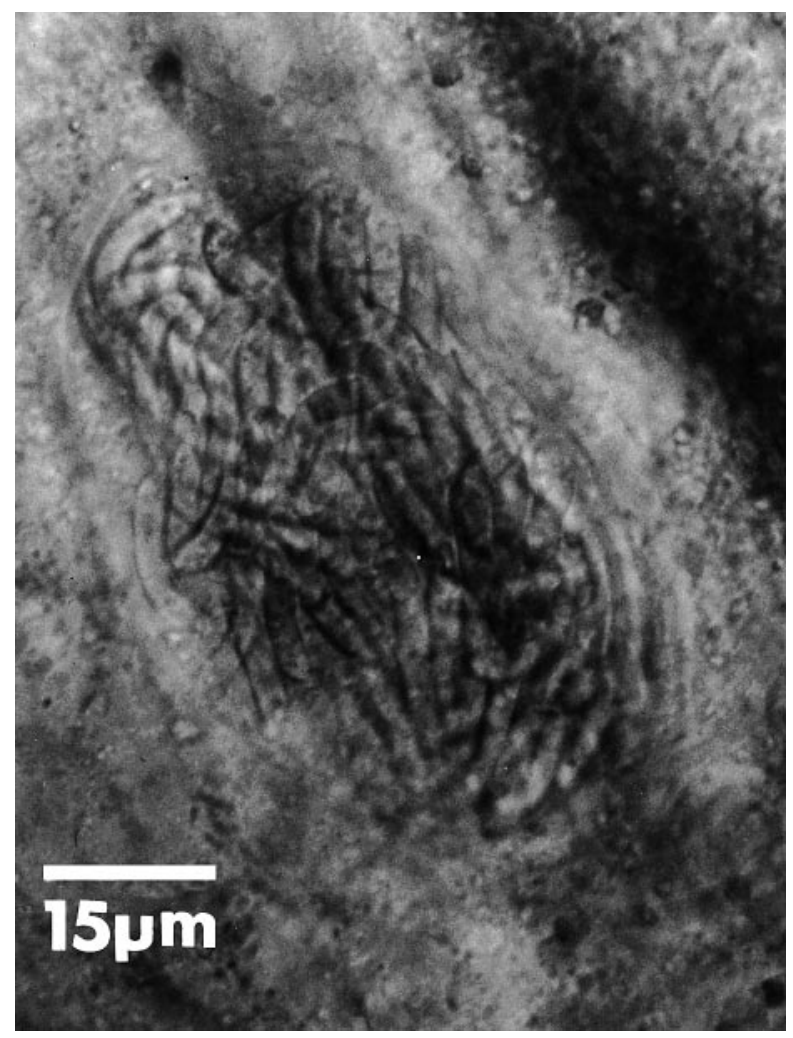

Fig. 2. Porospora sp. sporozoites enclosed within a cystic membrane in Callista chione 


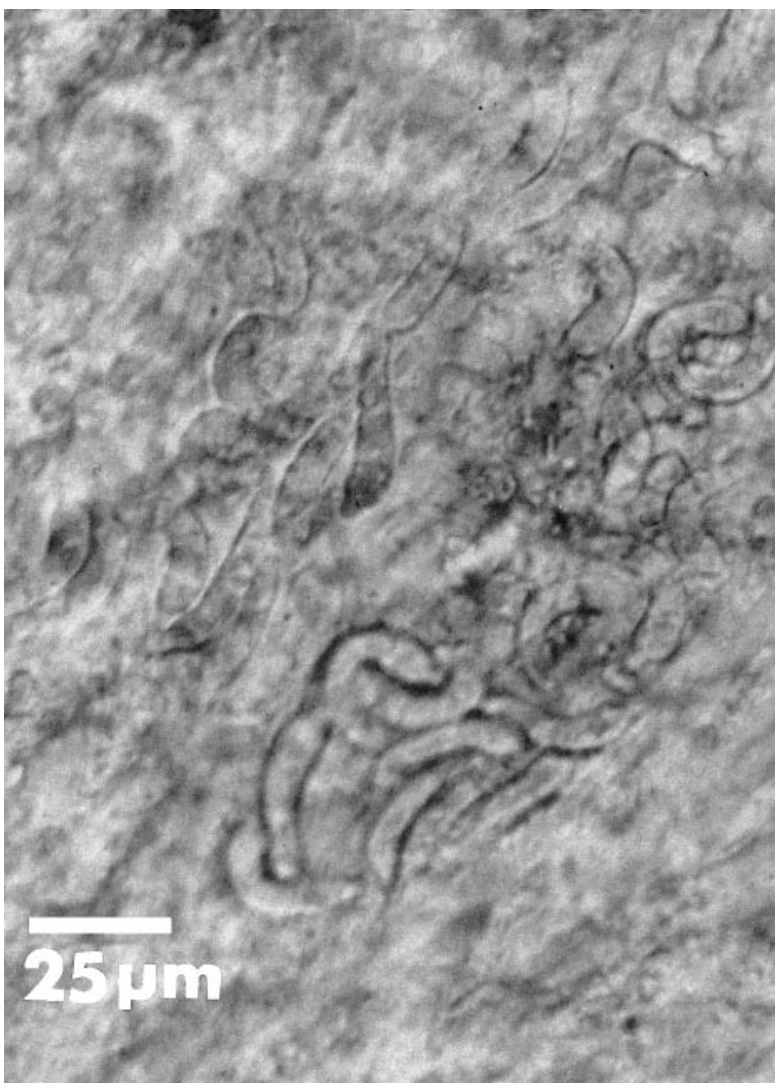

Fig. 3. Porospora sp. naked sporozoites in Callista chione

infected specimens, Porospora cystic sporozoites were frequently seen, while naked vermiform sporozoites ( $\mathrm{n}=1$ to 50 per microscope field) were irregularly distributed in the tissues and rarely observed.

In FTM Perkinsus sp.-infected bivalves were identified in the gills by the presence of round bodies (Fig. 4), corresponding to the hypnospore stage (Perkins 1996), measuring about 14.9 to $39.6 \mu \mathrm{m}$. The mean prevalence of Perkinsus sp. infection was $27.5 \%$, ranging from $9.1 \%$ observed in January to $50 \%$ in February 1998 (Table 1). The hypnospores ( $\mathrm{n}=1$ to 2 per microscope field) appeared irregularly distributed in the infected specimen tissues.

Out of 375 examined specimens, 128 (34.1\%) were simultaneously parasitized by Nematopsis sp. and Porospora sp. Out of the 229 specimens examined between January and November 1998, 17 (7.4\%) were parasitized by both Nematopsis sp. and Perkinsus sp., $52(22.7 \%)$ by both Porospora sp. and Perkinsus sp., and $12(5.2 \%)$ by Nematopsis sp., Porospora sp. and Perkinsus sp.

Discussion. Porospora sp. was the most common protozoan parasite in Callista chione (86.7\%), followed by Nematopsis sp. (39.7\%) and Perkinsus sp. (27.5\%). The simultaneous presence of 2 or 3 protozoan para-

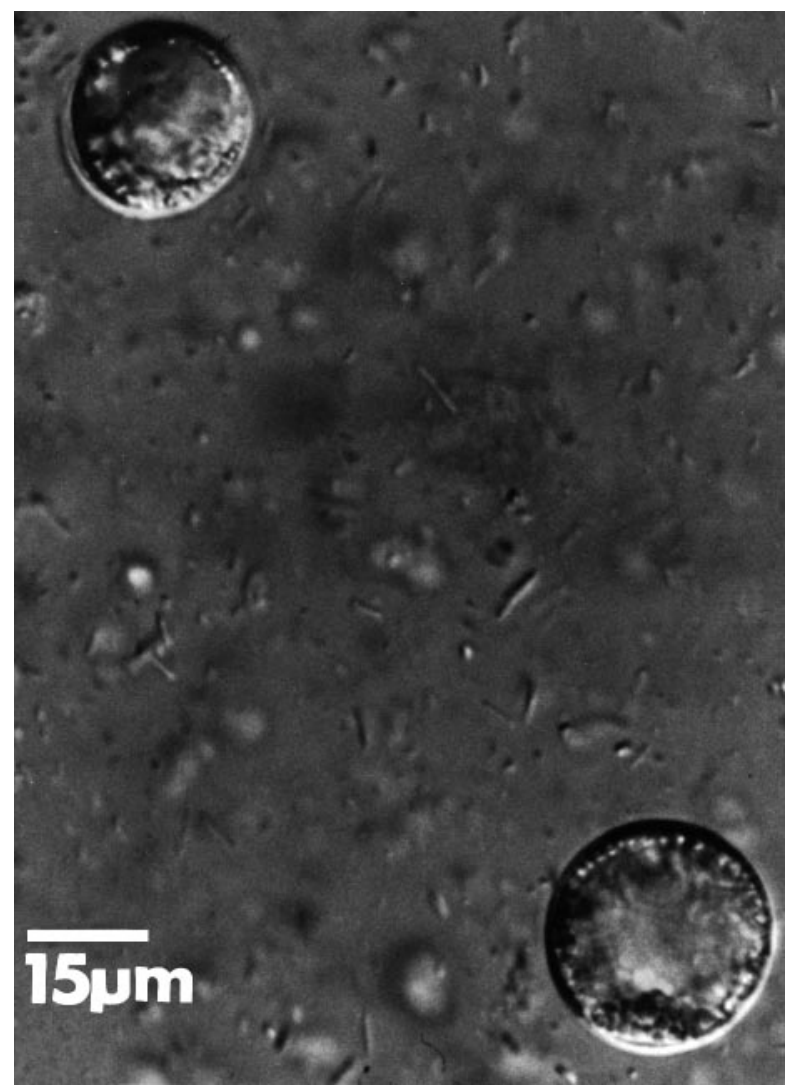

Fig. 4. Perkinsus sp. hypnospores in Callista chione

sites in the same specimen was also frequent. To our knowledge this is the first report of Porospora sp. and Perkinsus sp. in C. chione. We have not found reports about the presence of Porospora sp. infections in edible bivalves from Italian waters.

The genus Porospora includes 2 species (Levine 1988): P. gigantea and P. nephropis. They possess a heteroxenous life cycle that alternates between a decapod crustacean, in which gymnospores develop, and a marine mollusc, the intermediate host. In the latter, a fusiform bundle of sporozoites develops, which is held together by a fragile membrane (Sprague 1970). There are few reports on the pathogenicity of Porospora spp. in bivalves. Hatt (1931) reported that the gymnospore causes lesions, disorganization, atrophy and destruction of the epithelial tissue by penetrating the mollusc gill surface.

We observed, very often, a large number of Porospora sp. cystic sporozoites in infected specimens and, less frequently, naked vermiform sporozoites. Prevalences were almost always very high (100\% or close to $100 \%)$ during the years of study (low prevalences were observed only in March and November 1998).

Nematopsis sp. infections were observed for the first time in Callista chione from Chioggia (Venice) by 
Canestri-Trotti et al. (1998a), where the prevalence was $60.2 \%$. They were also reported in other edible bivalves of Italian waters: Chamelea gallina, Donax semistriatus, D. trunculus, Ensis siliqua minor, Ensis sp., Mytilus galloprovincialis, Ruditapes philippinarum, and Solen marginatus (Da Ros \& Massignan 1985, Costa et al. 1985-1986, Di Cave et al. 1987, Ceccarelli et al. 1988, Bilei et al. 1997, Berilli et al. 1998, CanestriTrotti et al. 1998a,b, 1999a,b).

The genus Nematopsis includes more than 30 species (Levine 1988, Belofastova 1996) that have a heteroxenous life cycle shared between a marine mollusc intermediate host, in the connective tissues of which sporogony takes place, and a decapod crustacean primary host, in the gut of which the sexual and asexual multiplication occurs. There are some discrepancies about the pathological significance of Nematopsis infections in bivalves. Recently, Azevedo \& Cachola (1992) showed that the infection in Cerastoderma edule and Ruditapes decussatus causes lysis of the nearby gill cells (suggesting that the parasite does have pathological consequences).

We observed a large number of oocysts in some infected Callista chione specimens; however, the branchial tissues of $C$. chione were never as densely occupied by broad oocyst clusters as we frequently saw in Chamelea gallina (Canestri-Trotti et al. 1998b). The mean prevalence $(39.7 \%)$ was lower than that we have reported in C. gallina $(96.5 \%)$; conversely, it was remarkably higher than that reported in Mytilus galloprovincialis (7\%) (Canestri-Trotti et al. 1999a) and in Ruditapes philippinarum (0.6-0.7\%) (Canestri-Trotti et al. 1999b). The monthly prevalences were inconstant during the years of study; however, the highest prevalences were reported mainly in autumn to early winter (November and December 1996, October and November 1997 and October 1998) except once in March 1998.

Perkinsus sp. infections have been observed in Italian waters in Ruditapes decussatus, Ostrea edulis, Crassostrea gigas, Venerupis aurea, Venus verrucosa, Cerastoderma edule, Chamelea gallina and recently in Mytilus galloprovincialis (Breber 1985, Da Ros \& Canzonier 1985, Ceschia et al. 1991, Berilli et al. 1998, Canestri-Trotti et al. 1999a). Ceschia et al. (1991) also examined 100 specimens of Callista chione sampled from the Northern Adriatic Sea, but none of these proved positive for Perkinsus sp.

The genus Perkinsus includes P. marinus, P. atlanticus and P. olseni reported in 67 species of molluscs (Perkins 1993), frequently associated with high mortality in bivalves (Lauckner 1983, Bower et al. 1994, Perkins 1996). Transmission of infection is direct from mollusc to mollusc. The parasite apparently penetrates the epithelium of the gill or gut or is carried through it by haemocytes. Multiplication occurs mainly in the connective tissue or between the epithelial cells; a large numbers of parasitic cells may develop and cause extensive tissue damage before death of the mollusc.

While the parasite growth, proliferation and consequent mortality have been correlated with increases in water temperature and salinity (Perkins 1993), our monthly findings were inconstant during the 1998 (highest prevalences in February, June and October). Compared to earlier studies carried out on Perkinsus sp. infections in other bivalves living in the Adriatic Sea, the Perkinsus sp. prevalence and intensity that we observed in Callista chione, in the sampled zones, was relatively low. Ceschia et al. (1991), Ceschia (1995), Orel et al. (1998), Restani et al. (1998) and CanestriTrotti et al. (1999b) found prevalences of 40-90, 68.2, $80.8,65-100$ and $30.3-50.3 \%$ respectively in Ruditapes philippinarum. Ceschia \& Giorgetti (1998) and Berilli et al. (1998) found prevalences of 92.3 and $30-60-100 \%$ respectively in Chamelea gallina. Canestri-Trotti et al. (1999a) found a prevalence of $20.5 \%$ in Mytilus galloprovincialis. There are no data about mass mortality of $C$. chione from the Northern Adriatic Sea; nevertheless, it is known that Perkinsus-like organisms are currently the most worrisome of the parasites we observed.

Acknowledgements. This research was aided by a grant from the Italian Ministero Universita Ricerca Scientifica Tecnologica. Fondi $40 \%$ e $60 \%$.

\section{LITERATURE CITED}

Azevedo C, Cachola R (1992) Fine structure of the apicomplexa oocyst of Nematopsis sp. of two marine bivalve molluscs. Dis Aquat Org 14:69-73

Belofastova IP (1996) Gregarines of the genus Nematopsis (Eugregarinida: Porosporidae), parasites of Black Sea molluscs. Parasitologiya 30(2):159-173

Berilli F, Ceschia G, Basilicata L, De Liberato C, Di Cave D, Mokhamer E, Orecchia P (1998) Monitoraggio parassitologico di Chamelea gallina (Mollusca, Bivalvia) in Adriatico. Parassitologia 40(Suppl 1):12

Bilei S, Tiscar PG, Marsilio F, Falchi A, Palazzini N (1997) Indagine sulle patologie presenti in cannolicchi (Ensis sp.) raccolti lungo la costa laziale. Boll Soc It Patol Ittica 21: $20-25$

Bower SM, McGladdery SE, Price IM (1994) Synopsis of infections diseases and parasites of commercially exploited shellfish. Annu Rev Fish Dis 4:1-199

Breber P (1985) On growing of the carpet-shell clam (Tapes decussatus (L.)): two years' experience in Venice Lagoon. Aquaculture 44:51-56

Canestri-Trotti G, Baccarani EM, Paesanti F (1998a) Gregarine del genere Nematopsis (Apicomplexa: Porosporidae) in molluschi bivalvi del Mar Adriatico. Boll Soc It Patol Ittica 23:58-66

Canestri-Trotti G, Baccarani EM, Paesanti F (1998b) Nematopsis spp. Schneider, 1982 (Apicomplexa: Gregarinida: 
Porosporidae) in Chamelea gallina from Adriatic Sea (Italy). Parassitologia 40(Suppl 1):28

Canestri-Trotti G, Baccarani EM, Paesanti F, Turolla E (1999a) Infezioni parassitarie in mitili (Mytilus galloprovincialis) provenienti da Goro (Ferrara - Nord Adriatico - Italia). Boll Soc It Patol Ittica 26:40-48

Canestri-Trotti G, Baccarani EM, Paesanti F, Turolla E (1999b) Monitoraggio delle infezioni da protozoi dei generi Nematopsis e Perkinsus in vongole filippine (Ruditapes philippinarum) del Nord Adriatico. Atti Soc It Sci Vet 53:191-192

Ceccarelli P, Costa C, Letardi A, Morresi L, Orecchia P, Rambaldi E, Volterra L (1988) Indagine sui molluschi bivalvi di interesse commerciale (telline, vongole, cannolicchi) delle coste della Toscana del Lazio e della Campania. Atti seminari Unità operative responsabili progetti ricerca piano pesca acquacoltura Ministero Marina Mercantile e CNR, Roma 1:421-478

Ceschia G (1995) Indagine sanitaria sulle vongole (Ruditapes philippinarum) allevate in Friuli-Venezia Giulia. In: Berletti M, Rossi R, Spreafico E (eds) PIM per le zone lagunari dell'Adriatico settentrionale. Ricerche e Sperimentazioni 1988-1994. Regione del Veneto, Venice, p 336-340

Ceschia G, Giorgetti G (1998) Valutazione dei fattori che possono incrementare la mortalità naturale nelle popolazioni di bivalvi Veneridi: ricerca di agenti patogeni. Biol Mar Medit 5(3):1662-1666

Ceschia G, Zentilin A, Giorgetti G (1991) Presenza di Perkinsus in vongole veraci (Ruditapes philippinarum) allevate nel Nord-Est Italia. Boll Soc It Patol Ittica 5:101-104

Costa C, Minervini R, Lombardi F, Volterra L, Orecchia P, Sequi R, Russo G (1985-1986) Indagine preliminare sulla pesca delle telline in provincia di Latina. Quaderni Ist Idrobiologia Acquacolt Brunelli 5-6:43-55

Da Ros L, Canzonier WJ (1985) Perkinsus, a protistan threat to bivalve culture in the Mediterranean basin. Bull Eur Assoc Fish Pathol 5(2):23-27

Da Ros L, Massignan F (1985) Indagine parassitologica su Mytilus galloprovincialis Lmk allevato in laguna di Venezia (Bacino di Chioggia). Oebalia 11(3) N.S:809-811

Di Cave D, Orecchia P, Paggi L (1987) Sulla presenza di Nematopsis sp. (Eugregarinida, Porosporidae) in molluschi bivalvi delle coste della Toscana, del Lazio e della

Editorial responsibility: Albert Sparks,

Seattle, Washington, USA
Campania. Atti XIX Congr Soc It Biol Mar, Napoli, 24-28 September 1987, p 135

Hatt P (1931) L'évolution des Porosporides chez les mollusques. Arch Zool Exp Gén 2:342-415

Lauckner G (1983) Diseases of Mollusca: Bivalvia. In: Kinne O (ed) Diseases of marine animals, Vol II, Introduction. Bivalvia to Scaphopoda. John Wiley \& Sons Chichester, p 532-550

Levine ND (1988) The protozoan phylum Apicomplexa, Vol I. CRC Press, Inc, Boca Raton, FL

Marano G, Vaccarella R, Pastorelli AM, Piccinetti C, Del Piero D (1998) Valutazione della biomassa di Callista chione (L.) (Fasolaro) in Adriatico. Biol Mar Medit 5(3):451-456

Orel G, Pessa G, Pavan B, Zamboni R, Ceschia G, Giorgetti G, Zentilin A (1998) Prove di allevamento di Tapes philippinarum (Adams and Reeve, 1850) in una valle della Laguna di Grado (Nord Adriatico). Biol Mar Medit 5(3): 1937-1946

Perkins FO (1993) Infectious diseases of mollusks. In: Couch JA, Fournie JW (eds) Pathobiology of marine and estuarine organisms. Advances in fisheries science. CRC Press, Inc, Boca Raton, FL

Perkins FO (1996) The structure of Perkinsus marinus (Mackin, Owen \& Collier, 1950) Levine, 1978 with comments on taxonomy and phylogeny of Perkinsus spp. J Shellfish Res 15(1):67-87

Ray SM (1952) A culture technique for the diagnosis of infections with Dermocystidium marinum (Mackin, Owen and Collier) in oysters. Science 116:360-361

Restani R, Caffara M, Fioravanti ML, Galuppi R, Minelli C, Tampieri MP, Delgado Montero ML, Quaglio F, Galuppi A, Gamberini R, Nobile L, Sigovini G, Zamperetti S, Tiscar PG (1998) Individuazione e definizione di modelli epidemiologici, diagnostici e terapeutici atti a controllare e prevenire le patologie virali, batteriche, micotiche e parassitarie degli animali acquatici allevati e pescati nel Delta Padano. Parte I: monitoraggio sanitario. Biol Mar Medit 5(3):2324-2332

Sprague V (1970) Some protozoan parasites and hyperparasites. In: Snieszko SF (ed) Marine bivalve molluscs. A symposium of diseases of fishes and shellfishes. Spec Publ 5, Am Fish Soc, Washington, DC, p 514-526

Submitted: June 30, 1999; Accepted: May 31, 2000

Proofs received from author(s): July 20, 2000 